\title{
Dry eye disease caused by viral infection: review
}

\section{Olho seco causado por infecções virais: revisão}

\author{
Monica Alves ${ }^{1,2}$, Rodrigo Nogueira Angerami ${ }^{3}$, Eduardo Melani Rocha ${ }^{1}$
}

\begin{abstract}
Dry eye disease and ocular surface disorders may be caused or worsened by viral agents. There are several known and suspected virus associated to ocular surface diseases. The possible pathogenic mechanisms for virus-related dry eye disease are presented herein. This review serves to reinforce the importance of ophthalmologists as one of the healthcare professional able to diagnose a potentially large number of infected patients with high prevalent viral agents.
\end{abstract}

Keywords: Dry eye syndromes/diagnosis; Eye infections, viral; Eye infections

\section{RESUMO}

A síndrome do olho seco e as doenças de superficie ocular podem ser causadas ou agravadas por agentes virais. Diversos vírus são causadores ou tem associação suspeitada com as doenças de superfície ocular. Esta revisão apresenta os possíveis mecanismos patogênicos envolvidos no olho seco causado por infecões virais e reinforça a importância do oftalmologista como um dos profissionais de saúde capazes de diagnosticar um grande número de pacientes infectados por agentes virais altamente prevalentes.

Descritores: Síndromes do olho seco; Infecções oculares virais; Infecções oculares

\section{INTRODUCTION}

Dry eye disease (DED) and ocular surface disorders may be caused or worsened by viral agents. There are several known and suspected virus associated to DED ${ }^{(1-3)}$. The pathogenic mechanisms and therapeutic approach for virus-related DED are reviewed herein.

The ocular surface comprises a unique and vital component of vision. The interface composed by cornea transparency and the tear film is a major refractive surface of the visual system ${ }^{(4-6)}$. All components of the ocular surface are intrinsic linked by the continuity of the epithelia to the tear film and by the reflex innervation and the endocrine, vascular and immune systems. The synergic function of the ocular surface components and the harmonic influence of the sensory and motor nerves, hormones and fluids are responsible for the maintenance of a regular, comfortable and perfect refractive surface ${ }^{(7-9)}$. In this context, viral infections might cause direct damage to the ocular surface, such as herpes virus or indirectly through interference in lacrimal gland function.

DED is a widely prevalent and multifactorial disorder involving multiple interacting mechanisms and a great range of signs and symptoms. Dysfunction of any component of the ocular surface and/ or tear film can lead to dry eye causing lower tear secretion, alterations in its composition and distribution and eventually leading to epithelial damage and inflammation ${ }^{(4)}$.

Sjögren syndrome is one of the most complicated forms of DED. It is a chronic disease affecting exocrine glands, mainly lacrimal and salivary ones, but also organs and systems can be involved. It is characterized by an aggressive lymphocytic infiltration and circulating autoantibodies that lead to damage and dysfunction of glands and target organs ${ }^{(1)}$. Although the pathogenesis of Sjögren Syndrome is considered a multifactorial process, it has been postulated that some viral infection could play a significant role on initiating and/or perpetrating the autoimmune response ${ }^{(10)}$.

Viruses can trigger autoimmune reactions through several mechanisms affecting different tissues in both animal models and humans. Virus infection can induce neoantigen expression due to molecular mimicry between viral and host antigens resulting in the production of autoantibodies, cytotoxic T-cell or both directed to different host tissues ${ }^{(11)}$. Once the innate immune response is initiated in glandular and dendritic cells there is an up-regulation of adhesion proteins and an increased production of chemokines that become activated and start acting as antigen-presenting cells. Those events could eventually lead to overproduction of immunoglobulins, autoantibodies and memory lymphocytes and subsequently tissue damage and dysfunction due to apoptosis and inflammation ${ }^{(12)}$.

The occurrence of Sjögren syndrome-like illness, reported as dry eye symptoms or signs, in patients having confirmed viral infections, such as human T-cell lymphotropic virus (HTLV), human immunodeficiency virus (HIV), Epstein-Barr virus (EBV), and hepatitis C virus (HCV), as well as the beneficial effect of anti-viral treatment, brings circumstantial evidence that their mechanism maybe pathogenically associated ${ }^{(3,13)}$.

The aim of this review is to summarize the knowledge on the role of virus infection in the pathogenesis of DED, plausible mechanisms and implications for diagnosis and therapeutic strategies.

\section{VIRAL INFECTIONS RELATED DO DRY EYE}

The best-studied viral agents related to systemic infection and DED manifestation are HTLV, HIV, HCV and EBV. Table 1 shows major characteristics of those viruses.
Submitted for publication: January 16,2013

Accepted for publication: January 31, 2013

Study carried out at Universidade de São Paulo, Ribeirão Preto (SP), Brazil.

Universidade de São Paulo, USP - Ribeirão Preto (SP), Brazil.

2 Pontifícia Universidade Católica de Campinas, PUC Campinas - Campinas (SP), Brazil.

${ }^{3}$ Universidade Estadual de Campinas, Unicamp - Campinas (SP), Brazil.
Funding: No specific financial support was available for this study.

Disclosure of potential conflicts of interest: M.Alves, None; R.N.Angerami, None; E.M.Rocha, None. Correspondence address: Monica Alves. Departamento de Oftalmologia, Otorrinolaringologia e Cirurgia de Cabeça e Pescoço. Faculdade de Medicina de Ribeirão Preto. Universidade de São Paulo. Av. Bandeirantes, 3900 - Ribeirão Preto (SP) - 14049-900 - Brazil

E-mail: monicalves@fmrp.usp.br 
The potential pathogenic mechanisms to DED associated to the viral infection in the lacrimal gland are the following:

\section{HTLV}

The human T-cell lymphotropic virus (HTLV) infection is endemic in Japan, the Caribbean basin, Central and South America and Africa. It is transmitted through sexual intercourse, breast-feeding, blood transfusion and sharing of contaminated syringes and needles. HTLV is characterized by asymptomatic infection in most of seropositive cases. Although $90 \%$ of the approximately 20 million infected people worldwide remain asymptomatic carriers during their lives, HTLV infection is also associated with systemic and ocular complications ${ }^{(14)}$.

HTLV infection is etiologically linked to two potential fatal diseases: 1) the malignant proliferation of T cell causing the adult leukemia/lymphoma (ATL) and 2) a neuromyelopathy known as tropical spastic paraparesis (TSP). ATL is considered an aggressive lymphoproliferative malignancy with short survival in its acute form, occurring in less than 5\% in HTLV infected people. TSP is a chronic meningomyelitis in the spinal cord, with demyelination and axonal degeneration leading to the development of a slowly progressive spastic paraparesis, high impairment of gait, autonomic dysfunction and profound repercussions on abilities and quality of life of the patients ${ }^{(15,16)}$. HTLV also causes dermatitis, pneumonia, polymyositis, thyroiditis and Sjögren's like syndrome ${ }^{(16)}$.

HTLV ocular lesions may present as uveitis, dry eye, keratitis and retinal vasculitis ${ }^{(17)}$. The prevalence of uveitis is controversial in different parts of the world. In Japan, for instance, a 35.4\% prevalence of uveitis in patients infected with HTLV was observed, while in Martinique, the prevalence was $14.5 \%{ }^{(18)}$. The incidence of dry eye in seropositive patients was $36.4 \%$ in study conducted in the region of highest prevalence of HTLV infection in Brazil. Moreover, $54.4 \%$ of DED in TSP patients and $20.3 \%$ in asymptomatic seropositives. In those patients immunophenotyping analysis shown high levels of both CD4+ and CD8 $+{ }^{(19)}$. Another study, evaluating 200 infected patient found $37 \%$ of DES accompanied by lymphoplasmocytoid infiltration of secondary salivar gland(20,21).

Serological studies demonstrated the prevalence of antibodies to HTLV in Sjögren patients ranging from 23-36\%, significantly higher than that among blood donors. Salivary IgA antibodies to HTLV were found in seropositive HTLV patients with SS ${ }^{(22,23)}$. Indeed, two independent studies confirmed the presence of HTLV genome in salivary glands samples from patients with Sjögren ${ }^{(24,25)}$.

\section{HIV}

HIV (human immunodeficiency virus) infection may present with a large variety of primary and secondary (caused by opportunistic infections) ocular manifestations, some of those have threatening potential to vision and life quality. The incidence and presentation of the AIDS epidemic and its correlated complications have dramatically changed since the introduction of the potent antiretroviral therapies (also know as highly active antiretroviral therapy, or HAART), but remains as a dramatic public health in very low income countries.

DED appears to be much more prevalent among individuals with AIDS (21.4-38.8\% of HIV-infected men, 16.9\% of HIV-infected women) than in the general population $n^{(13,26,27)}$. Burtin et al. evaluated the ocular surface and DED complains in a group of HIV positive patients. According to this study, $70 \%$ of them had complained of DED symptoms, $85 \%$ present at least one clinical sign of ocular surface dysfunction tested through Schirmer test, tear break-up time and lissamine stain and the impression cytology revealed a decrease in the number of dendritic cells ${ }^{(28)}$.

Geier et al. showed that decreased tear production occurs in approximately $20 \%$ to $25 \%$ of patients with HIV infection without correlation with the CD4+v lymphocites blood count, or to the severity of HIV disease, in a group of 144 HIV patients ${ }^{(29)}$. Although the entire pathogenesis of the aqueous tear deficiency in HIV-infected remain unclear, it may be associated with lymphocytic infiltration and destruction of the lacrimal gland acini and ducts.

In fact, a Sjögren's syndrome-like picture may be present in HIV -infected patients who develop the diffuse infiltrative lymphocytosis syndrome (DILS). Thus, it is an exclusion criteria for individuals under investigation for Sjögren syndrome ${ }^{(30)}$. DILS is a disorder in patients with HIV infection that is characterized by the enlargement of salivary and lacrimal glands and a varying intensity of DED symptoms. In addition, DILS is accompanied by persistent circulating and infiltration of CD8-positive lymphocytes. DILS may mimic Sjögren's syndrome in

Table 1. Major characteristics of virus associated to dry eye disease

\begin{tabular}{|c|c|c|c|c|}
\hline Virus & Type & Major clinical manifestation & $\begin{array}{l}\text { Major ocular } \\
\text { manifestation }\end{array}$ & Transmission \\
\hline HTLV & Retrovirus (Oncornavirus) & $\begin{array}{l}\text { Adult T-cell leukemia/lymphoma } \\
\text { Neuromyelopathy }\end{array}$ & $\begin{array}{l}\text { Uveitis } \\
\text { Dry eye }\end{array}$ & $\begin{array}{l}\text { Blood and blood products transfusion, } \\
\text { breastfeeding; sexual intercourse }\end{array}$ \\
\hline HIV & Retrovirus (Lentivirus) & Acquired immunodeficiency syndrome & Dry eye & $\begin{array}{l}\text { Sexual intercourse; blood and blood products } \\
\text { transfusion; maternal fetal; injection drug users; }\end{array}$ \\
\hline $\mathrm{HCV}$ & $\begin{array}{l}\text { RNA virus } \\
\text { (Flavivirus) }\end{array}$ & $\begin{array}{l}\text { Hepatitis } \\
\text { Cirrhosis } \\
\text { Liver failure } \\
\text { Hepatocellular carcinoma } \\
\text { Extrahepatic manifestations (e.g. glandular, renal, } \\
\text { dermatological, hematological, joints) }\end{array}$ & $\begin{array}{l}\text { Retinopathy } \\
\text { Scleritis } \\
\text { Keratitis } \\
\text { Dry eye }\end{array}$ & $\begin{array}{l}\text { Injection drug users; blood and blood products } \\
\text { transfusion; needlestick injuries in health care } \\
\text { settings; sexual intercourse (rare); maternal fetal } \\
\text { (rare); contaminated needles and instruments } \\
\text { (tattoo, piercings) }\end{array}$ \\
\hline EBV & DNA virus (Herpesvirus) & $\begin{array}{l}\text { Infectious mononucleosis } \\
\text { Burkitt's lymphoma } \\
\text { Nasopharingeal carcinoma }\end{array}$ & Dry eye & $\begin{array}{l}\text { Exchanging of saliva } \\
\text { Direct contact }\end{array}$ \\
\hline
\end{tabular}

$H T L V=$ human $T$-cell lymphotropic virus; $H I V=$ human immunodeficiency virus; $H C V=$ hepatitis $C$ virus; $E B V=$ Epstein-Barr virus; $H S V-1=$ herpes simplex virus-1. 
terms of symptoms and parotid and lacrimal glands involvement. On the other hand, it differs by the high frequency of extra glandular sites of lymphocytic infiltration, such as lungs, muscles and liver, scarcity or absence of serum autoantibodies and the nature of infiltrating lymphocytes. While in Sjögren syndrome presents lymphocytic infiltration of CD4+ and in DILS it is a CD8+ lymphocytes and anti-Ro and anti-La are seen less frequently ${ }^{(2,31)}$. The prevalence of DILS had dropped significantly after the introduction of HAART, indirectly inferring that the HIV infection contributes to DILS pathogenesis.

\section{Hepatitis C}

Hepatitis C virus (HCV) is frequently associated with autoimmune features and extra hepatic manifestations, especially with chronic infection ${ }^{(32)}$. The prevalence of HCV infection in patients with primary SS have been analyzed in different studies and its is comparatively higher than in the general population although varying geographically ${ }^{(3,33,34)}$.

Ocular manifestations such as retinopathy, scleritis and keratitis have been well documented ${ }^{(35)}$. Cacoub et al. evaluating a group of 312 HCV patients found xerostomia and/or xeroftalmia symptoms in $10 \%{ }^{(36)}$ which makes the ocular surface one of the most important sites of manifestations in HCV infected patients ${ }^{(37)}$.

Both entities, Sjögren syndrome and HCV, are characterized by B-cell hyperactivity although related to different etiologies, autoimmune and infectious respectively. HCV have demonstrated capability to infect and replicate in the salivary and lacrimal gland tissues leading to lymphocytic infiltration, signs and symptoms of SS. Patients with Sjögren syndrome associated to HCV infection have demographic, immunological and clinical different profiles. Comparatively, Sjögren syndrome-HCV patients are older aged, higher incidence of extra glandular manifestations, especially cryoglobulinemia, and have negative Ro/La antibodies and hypocomplementemia.

Again the American European criteria for Sjögren syndrome, exclude Sjögren diagnosis in patients who are HCV positive ${ }^{(30)}$.

\section{EBV}

EBV (Epstein Barr virus) is herpes virus that infects epithelial cell located in oropharyngeal tissues, salivary glands and B-lymphocytes. The virus occurs worldwide and most people become infected with EBV during the first two decades of life. In the United States, as many as 95\% of adults between 35 and 40 years of age have been infected. Primary EBV infection is usually asymptomatic and resolves spontaneously. Occasionally, EBV infection may cause infectious mononucleosis characterized by fever, pharyngitis and general lymphadenopathy ${ }^{(38)}$. After the primary infections it remains latent and occasionally reactivates in salivary glands ${ }^{(39)}$. EBV infection of B cell activates intrinsic pathway that results on continuous cellular division and consequently lymphoproliferation.

There is increasing evidence suggesting that EBV infection may be related to lacrimal gland lymphocytic proliferation of Sjögren syndrome, which leads to decreased aqueous tear production and severe DED ${ }^{(40,41)}$. Many studies have reported primary Sjögren syndrome development immediately after serological confirmation of infectious mononucleosis ${ }^{(42-44)}$. EBV genome has been amplified from the majority of lacrimal gland biopsies of Sjögren patients postulating that EBV may be considered a risk factor for the lacrimal gland pathologic mechanisms of Sjögren syndrome ${ }^{(43)}$. Salivary and lacrimal glands differ in the type of EBC infection observed in biopsies from Sjögren patients. Minor salivary gland shows CD4 T cells infiltration and less severe inflammation. On the other hand, in lacrimal gland biopsies the infiltrating cell type is predominately B-lymphocytes and EBV antigen and EBV DNA are detected in ductal epithelia associated high levels of lymphoproliferation surrounding infected ducts or focci replacing secretory acini(45).

\section{HSV AND OCULAR SURFACE}

HSV-1 (herpes simplex virus-1) ocular infection is a common cause of ocular surface disorder. It can present in a broad range of manifestations from primary blepharoconjuntivitis to recurrent forms of keratitis and even intraocular involvement as that seen in retinitis and uveitis ${ }^{(46,47)}$. Although there is no evidence of HVS direct infection in the lacrimal gland it has been demonstrated that corneal sensation and tear production are significant lower in patients with ocular herpetic disease ${ }^{(48,49)}$.

\section{CONCLUSIONS}

Circumstantial evidence suggests that systemic and ocular viral infections, along with many environmental and other risks factors, may play an important role in the pathogenesis of dry eye disease. Patients with moderate to severe dry eye disease and other clinical manifestations should be investigated by serology of mentioned viral systemic infections. Many studies confirmed the association of viruses and lacrimal gland dysfunction and many others have been addressed efforts to the understanding its mechanisms. Future research should characterize this subpopulation, the application of diagnostic tools and the possible benefits of specific antiviral treatment as a therapeutic approach for dry eye disease.

Finally, the present review reinforces the importance of ophthalmologists as one of the healthcare professional able to diagnose a potentially large number of infected patients with high prevalent viral agents. Moreover, it may contribute to make more widely known the possible association between viral infections and dry eye disease and the importance of including an ophthalmologic evaluation as part of the medical approach to patients infected with specific chronic viral infections.

\section{REFERENCES}

1. Sipsas NV, Gamaletsou MN, Moutsopoulos HM. Is Sjögren's syndrome a retroviral disease? Arthritis Res Ther. 2011;13(2):212. Review.

2. Vitali C. Immunopathologic differences of Sjögren's syndrome versus sicca syndrome in HCV and HIV infection. Arthritis Res Ther. 2011:13(4):233.

3. Ramos-Casals M, García-Carrasco M, Brito Zerón MP, Cervera R, Font J. Viral etiopathogenesis of Sjögren's syndrome: role of the hepatitis C virus. Autoimmun Rev. 2002; 1(4):238-43.

4. The definition and classification of dry eye disease: report of the Definition and Classification Subcommittee of the International Dry Eye WorkShop (2007). Ocul Surf. 2007;5(2):75-92.

5. Gipson IK. The ocular surface: the challenge to enable and protect vision: the Friedenwald lecture. Invest Ophthalmol Vis Sci. 2007:48(10):4390; 4391-8.

6. Pflugfelder SC. Tear dysfunction and the cornea: LXVIII Edward Jackson Memorial Lecture. Am J Ophthalmol. 2011;152(6):900-9.e1.

7. Williams K, Watsky M. Gap junctional communication in the human corneal endothelium and epithelium. Curr Eye Res. 2002;25(1):29-36.

8. Pflugfelder SC. Tear fluid influence on the ocular surface. Adv Exp Med Biol. 1998; 438:611-7.

9. Tseng SC, Tsubota K. Important concepts for treating ocular surface and tear disorders. Am J Ophthalmol. 1997;124(6):825-35. Review.

10. Mitsias DI, Kapsogeorgou EK, Moutsopoulos HM. The role of epithelial cells in the initiation and perpetuation of autoimmune lesions: lessons from Sjögren's syndrome (autoimmune epithelitis). Lupus. 2006;15(5):255-61.

11. Moutsopoulos HM, Papadopoulos GK. Possible viral implication in the pathogenesis of Sjögren's syndrome. Eur J Med. 1992;1(4):219-23. Review.

12. Katsifis GE, Moutsopoulos NM, Wahl SM. T lymphocytes in Sjögren's syndrome: contributors to and regulators of pathophysiology. Clin Rev Allergy Immunol. 2007; 32(3):252-64

13. DeCarlo DK, Penner SL, Schamerloh RJ, Fullard RJ. Dry eye among males infected with the human immunodeficiency virus. J Am Optom Assoc. 1995;66(9):533-8.

14. de Thé G, Bomford R. An HTLV-I vaccine: why, how, for whom? AIDS Res Hum Retroviruses. 1993;9(5):381-6.

15. Proietti FA, Carneiro-Proietti AB, Catalan-Soares BC, Murphy EL. Global epidemiology of HTLV-I infection and associated diseases. Oncogene. 2005;24(39):6058-68.

16. Goncalves DU, Proietti FA, Ribas JG, Araújo MG, Pinheiro SR, Guedes AC, et al. Epidemiology, treatment, and prevention of human T-cell leukemia virus type 1-associated diseases. Clin Microbiol Rev. 2010;23(3):577-89. Review. 
17. Kamoi K, Mochizuki M. HTLV infection and the eye. Curr Opin Ophthalmol. 2012; 23(6):557-61.

18. Mochizuki M, Watanabe T, Yamaguchi K, Yoshimura K, Nakashima S, Shirao M, et al. Uveitis associated with human T-cell lymphotropic virus type I. Am J Ophthalmol. 1992;114(2):123-9.

19. Pinheiro SR, Martins-Filho OA, Ribas JG, Catalan-Soares BC, Proietti FA, Namen-Lopes $S$, et al. Immunologic markers, uveitis, and keratoconjunctivitis sicca associated with human T-cell lymphotropic virus type 1. Am J Ophthalmol. 2006;142(5):811-5.

20. Merle H, Cabre P, Olindo S, Merle S, Smadja D. Ocular lesions in 200 patients infected by the human T-cell lymphotropic virus type 1 in martinique (French West Indies). Am J Ophthalmol. 2002;134(2):190-5.

21. Yamamoto JH, Segurado AA, Hirata CE, Sampaio MW, Souza EC, Nukui Y, et al. Human T-cell lymphotropic virus type 1 infection and ocular manifestations in Sao Paulo, Brazil. Arch Ophthalmol. 1999;117(4):513-7.

22. Eguchi K, Matsuoka N, Ida H, Nakashima M, Sakai M, Sakito S, et al. Primary Sjögren's syndrome with antibodies to HTLV-l: clinical and laboratory features. Ann Rheum Dis. 1992;51(6):769-76.

23. Terada K, Katamine S, Eguchi K, Moriuchi R, Kita M, Shimada $H$, et al. Prevalence of serum and salivary antibodies to HTLV-1 in Sjögren's syndrome. Lancet. 1994; 344(8930):1116-9. Comment in Lancet. 1995;345(8941):71-2.

24. Sumida T, Yonaha F, Maeda T, Kita Y, Iwamoto I, Koike T, et al. Expression of sequences homologous to HTLV-I tax gene in the labial salivary glands of Japanese patients with Sjögren's syndrome. Arthritis Rheum. 1994;37(4):545-50.

25. Mariette X, Agbalika F, Daniel MT, Bisson M, Lagrange P, Brouet JC, et al. Detection of human T lymphotropic virus type I tax gene in salivary gland epithelium from two patients with Sjögren's syndrome. Arthritis Rheum. 1993;36(10):1423-8. Comment in Arthritis Rheum. 1996;39(9):1609-11.

26. Lucca JA, Farris RL, Bielory L, Caputo AR. Keratoconjunctivitis sicca in male patients infected with human immunodeficiency virus type 1. Ophthalmology. 1990;97(8): 1008-10.

27. Lucca JA, Kung JS, Farris RL. Keratoconjunctivitis sicca in female patients infected with human immunodeficiency virus. Clao J. 1994;20(1):49-51.

28. Burtin T, Guepratte N, Bourges JL, Garcher C, Le Hoang P, Baudouin C. [Abnormalities of the ocular surface in patients with AIDS]. J Fr Ophtalmol. 1998;21(9):637-42. French.

29. Geier SA, Libera S, Klauss V, Goebel FD. Sicca syndrome in patients infected with the human immunodeficiency virus. Ophthalmology. 1995;102(9):1319-24. Erratum in Ophthalmology 1996;103(2):204.

30. Vitali C. Classification criteria for Sjögren's syndrome. Ann Rheum Dis. 2003;62(1):94-5; author reply 95 .

31. Kordossis T, Paikos S, Aroni K, Kitsanta P, Dimitrakopoulos A, Kavouklis E, et al. Prevalence of Sjögren's-like syndrome in a cohort of HIV-1-positive patients: descriptive pathology and immunopathology. Br J Rheumatol. 1998;37(6):691-5.

32. Ramos-Casals M, Jara LJ, Medina F, Rosas J, Calvo-Alen J, Mañá J, Anaya JM, Font J; HISPAMEC Study Group. Systemic autoimmune diseases co-existing with chronic hepatitis C virus infection (the HISPAMEC Registry): patterns of clinical and immunological expression in 180 cases. J Intern Med. 2005;257(6):549-57.

33. Verbaan H, Carlson J, Eriksson S, Larsson A, Liedholm R, Manthorpe R, et al. Extrahepatic manifestations of chronic hepatitis $C$ infection and the interrelationship between primary Sjögren's syndrome and hepatitis C in Swedish patients. J Intern Med. 1999;245(2):127-32.

34. King PD, McMurray RW, Becherer PR. Sjögren's syndrome without mixed cryoglobulinemia is not associated with hepatitis C virus infection. Am J Gastroenterol. 1994; 89(7):1047-50

35. Baratz KH, Fulcher SF, Bourne WM. Hepatitis C-associated keratitis. Arch Ophthalmol. 1998;116(4):529-30.

36. Cacoub P, Renou C, Rosenthal E, Cohen P, Loury I, Loustaud-Ratti V, et al. Extrahepatic manifestations associated with hepatitis $C$ virus infection. A prospective multicenter study of 321 patients. The GERMIVIC. Groupe d'Etude et de Recherche en Medecine Interne et Maladies Infectieuses sur le Virus de I'Hepatite C. Medicine (Baltimore). 2000;79(1):47-56

37. Gomes RL, Marques JC, Albers MB, Endo RM, Dantas PE, Felberg S. Superfície ocular e hepatite C. Arq Bras Oftalmol. 2011:74(2):97-101.

38. Cohen Jl. Epstein-Barr virus infection. N Engl J Med. 2000;343(7):481-92.

39. Pflugfelder SC, Crouse CA, Atherton SS. Ophthalmic manifestations of Epstein-Barr virus infection. Int Ophthalmol Clin. 1993;33(1):95-101.

40. Whittingham S, McNeilage J, Mackay IR. Primary Sjögren's syndrome after infectious mononucleosis. Ann Intern Med. 1985;102(4):490-3.

41. Pflugfelder SC, Wilhelmus KR, Osato MS, Matoba AY, Font RL. The autoimmune nature of aqueous tear deficiency. Ophthalmology. 1986;93(12):1513-7.

42. Pflugfelder SC, Roussel TJ, Culbertson WW. Primary Sjögren's syndrome after infectious mononucleosis. JAMA. 1987;257(8):1049-50.

43. Pflugfelder SC, Crouse C, Pereira I, Atherton S. Amplification of Epstein-Barr virus genomic sequences in blood cells, lacrimal glands, and tears from primary Sjögren's syndrome patients. Ophthalmology. 1990;97(8):976-84.

44. Gaston JS, Rowe M, Bacon P. Sjögren's syndrome after infection by Epstein-Barr virus. J Rheumatol. 1990;17(4):558-61.

45. Pflugfelder SC, Crouse CA, Monroy D, Yen M, Rowe M, Atherton SS. Epstein-Barr virus and the lacrimal gland pathology of Sjögren's syndrome. Am J Pathol. 1993;143(1):49-64.

46. Liesegang TJ, Melton LJ $3^{\text {rd }}$, Daly PJ, Ilstrup DM. Epidemiology of ocular herpes simplex. Incidence in Rochester, Minn, 1950 through 1982. Arch Ophthalmol. 1989; 107(8):1155-9.

47. Liesegang TJ. Herpes simplex virus epidemiology and ocular importance. Cornea. 2001; 20(1):1-13.

48. Keijser S, van Best JA, Van der Lelij A, Jager MJ. Reflex and steady state tears in patients with latent stromal herpetic keratitis. Invest Ophthalmol Vis Sci. 2002;43(1):87-91.

49. Simard-Lebrun A, Boisjoly H, Al-Saadi A, Choremis J, Mabon M, Chagnon M. Association between unilateral quiescent stromal herpetic keratitis and bilateral dry eyes. Cornea. 2010;29(11):1291-5. 